С.Ю. Макаров*

\title{
РАБОТА СЕКЦИИ АДВОКАТУРЫ И НОТАРИАТА НА VI КУТАФИНСКИХ ЧТЕНИЯХ
}

Аннотация: Данная статья посвящена работе секции адвокатуры и нотариата в рамках Кутафинских чтений 3 апреля 2014 года. Работа секции представляла собой проведение круглого стола, посвященного актуальным вопросам адвокатуры и нотариата. Участниками работы секции стали как теоретики, так и практики адвокатуры, а также нотариата. Среди участников были представители профессорско-преподавательского состава, выступившие с докладами по различным проблемным аспектам современного состояния адвокатуры, а также по вопросам истории адвокатуры, аспиранты и соискатели, обозначившие свои исследования в свете тем диссертационных исследований, практикующие адвокаты и помощники нотариусов. В статье приведены основные положения выступлений участников круглого стола, а также вопросы, обращенные к некоторым выступавшим в порядке дискуссии. Широта спектра проблем, поднятых в выступлениях участников работы секции, позволила затронуть такие вопросы, в частности, как финансовые результаты адвокатской деятельности, участие адвокатов в системе оказания бесплатной юридической помощи, профессиональное усовершенствование адвокатов, а также история адвокатуры в Древнем Риме, Франции и России, и отдельные аспекты адвокатской практики (гарантии независимости адвоката в уголовном процессе, новеллы Кодекса профессиональной этики адвоката, теории выбора дел, правовое положение стажеров и помощников адвоката, оказание адвокатами помощи детям-инвалидам). Кроме того, был представлен обзор современных изменений правового регулирования нотариальной деятельности.

Ключевые слова: адвокат, гонорар, профессиональное усовершенствование адвокатов, адвокатура и магистратура, сословие адвокатов, стажеры и помощники, независимость адвоката, бесплатная юридическая помощь, теории принятия поручений, нотариус.

DOI: 10.7256/1994-1471.2014.6.11996

3 апреля 2014 года в рамках проведения VI Кутафинских чтений состоялся круглый стол, посвященный актуальным вопросам адвокатуры и нотариата. Руководителем работы секции выступил Ю.С. Пилипенко, первый вице-президент Федеральной палаты адвокатов Российской Федерации, доктор юридических наук, профессор кафедры адвокатуры и нотариата Университета имени О.Е. Кутафина (МГЮА), заместителем руководителя секции выступил О.В. Поспелов, кандидат юридических наук, доцент кафедры адвокатуры и нотариата Университета имени О.Е. Кутафина (МГЮА). Организатором работы секции и соведущим выступила С.И. Володина, кандидат юридических наук, зам. зав. кафедры адвокатуры и нотариата, директор Института адвокатуры Университета имени О.Е. Кутафина (МГЮА), вице-президент Федеральной палаты адвокатов Российской Федерации.
В начале работы секции слово взял Ю.С. Пилипенко с выступлением на тему «Вознаграждение адвоката и справедливость». Его выступление получилось весьма интересным и разноплановым. Он привел разнообразные статистические данные, в частности - данные по повышению зарплаты и увеличению размера социального пакета в госструктурах (в частности в Правительстве Российской Федерации) - и предложил соотнести это с доходами адвокатов, в свете того, что адвокатура ратует за точное выполнение государством предусмотренных действующим законодательством России финансовых обязательств перед адвокатами.

Также Ю.С. Пилипенко привел весьма интересные данные по современному финансовому состоянию европейской адвокатуры. Так, он отметил, что в среднем по Германии адвокаты зарабатывают (до налогообложения) 60000 евро в год в восточной части страны и 80000

(C) Макаров Сергей Юрьевич

* Кандидат юридических наук, доцент кафедры адвокатуры и нотариата, Московская

государственная юридическая академия имени О.Е. Кутафина (МГЮА)

[makarov.msal@gmail.com]

123995, Россия, г. Москва, ул. Садовая-Кудринская, д. 9. 
евро в год в западной части страны. При этом судьи и прокуроры в Германии получают по 3000 евро в месяц; чтобы адвокат получал те же 3000 евро в месяц, ему, с учетом всех предусмотренных отчислений, каждый день нужно выставлять счета на 1000 евро. Он привел также факты того, что в Германии некоторые адвокаты вынуждены подрабатывать водителями такси, чтобы содержать семьи. На основании сопоставления этих данных он сделал совершенно обоснованный вывод о том, что российские адвокаты находятся не в самом худшем положении по сравнению со своими коллегами из некоторых зарубежных стран.

Также Ю.С. Пилипенко коснулся темы о «гонораре успеха», отметив роль Конституционного Суда России в отвержении этого института, но подчеркнув, что в последнее время Высший Арбитражный Суд России стал предлагать судам при определении взыскиваемого размера гонорара учитывать знание адвокатом научной доктрины и международной практики. По его мнению, главная цель обсуждения - необходимость постараться обозначить, что есть такая проблема, с тем чтобы прийти к ее решению.

Последовал вопрос Г.И. Сибирцева, преподавателя, аспиранта кафедры организации судебной власти и правоохранительной деятельности Воронежского государственного университета, о том, что гонорар успеха закреплен в Кодексе профессиональной этики адвоката нерешительно, только в отношении дел имущественного характера, и в связи с этим насколько гонорар успеха обоснован, с учетом того, что международные документы запрещают его. Ю.С. Пилипенко в ответ отметил, что в Германии и Швейцарии адвокатуры международного уровня нет, а вот в странах англосаксонской системы права адвокаты в полной мере используют гонорар успеха как форму оплаты адвокатской помощи.

С.Г. Смирнов, адвокат, аспирант кафедры предпринимательского права Финансового университета при Правительстве Российской Федерации, задал вопросы - имеют ли адвокаты право объединять свои базы клиентов, и как это влияет на адвокатскую тайну, и стоит ли ограничивать только адвокатами представительство в суде. Ю.С. Пилипенко в ответ отметил, что возможное объединение адвокатами баз информации о клиентах крайне плохо влияет на сохранение адвокатской тайны, и вследствие этого такое объединение нежелательно. В отношении представительства он отметил, что, по его мнению, гражданам и другим физическим лицам бесспорно должно быть сохранено право самостоятельно защищать свои интересы, либо обращаться за представительством к адвока- там, а юридические лица должны быть обязаны обращаться к адвокатам.

Далее Л.Н. Бардин, кандидат юридических наук, доцент, член Совета Адвокатской палаты г. Москвы, доцент кафедры судебной власти и организации правосудия Факультета права Национального исследовательского университета «Высшая школа экономики», выступил с докладом на тему «Оказание адвокатами бесплатной юридической помощи». Он отметил, что несмотря на вступление с 15 января 2012 года в силу соответствующего Федерального закона № 324-Ф3 до сих пор отсутствует порядок его реализации, что нередко влечет своеобразный, по выражению докладчика, «потребительский экстремизм» граждан, обращающихся за помощью к адвокатам.

Также Л.Н. Бардин охарактеризовал изменение политики Правительства Москвы (в свете Постановления Правительства Москвы от 15.10 .2013 г.), ранее предусматривавшего для адвокатских образований, 30 \% юрпомощи которых оказывалось бесплатно, льгот по оплате арендной платы. Выход он видит в том, что адвокатам нет никакой пользы участвовать в государственной системе бесплатной юридической помощи, а лучше всего участвовать в негосударственных центрах, так как участники этой системы могут получать льготы как некоммерческие организации. Кроме того, он отметил, что осуществление этой деятельности возможно на базе организаций образования, которые могут предоставлять площадку. Консультационную деятельность при этом будут осуществлять студенты юрклиник, а судебное представительство будут осуществлять адвокаты.

Следующим докладчиком стал Ч.Б. Далецкий, профессор кафедры адвокатуры и нотариата Университета имени О.Е. Кутафина (МГЮА), доктор философских наук, профессор, выступивший с докладом на тему «Значение риторики», в котором он подробно охарактеризовал роль преподавания риторики в подготовке практикующих юристов, и важное значение учебного курса риторики на 72 часа. В своем докладе он совершенно справедливо отметил заслугу С.И. Володиной, обеспечившей сохранение преподавания в Университете имени О.Е. Кутафина (МГЮА) риторики как учебного предмета. Также Ч.Б. Далецкий отметил отсутствие у студентов чувства стиля, и в связи с этим высказал довод об актуальности лозунга «Культура в опасности»; в свете этого он также подчеркнул важность курса культурологии для подготовки адвокатов.

Далее выступил В.В. Раудин, адвокат, аспирант кафедры адвокатуры и нотариата Университета имени О.Е. Кутафина (МГЮА), с докладом на тему «Изменение правил адвокатской 
профессии: новеллы Кодекса профессиональной этики адвоката и практика их применения». Он отметил такое важное изменение, что теперь адвокатам разрешено вести адвокатскую практику вне рамок адвокатуры - в сфере медиация, в третейских судах. Кроме того, он отметил существование модели «АО+O00» (когда партнеры адвокатского бюро или реже учредители коллегии адвокатов становятся учредителями 000 с тем же названием, располагающегося по тому же адресу). При этом он подчеркнул, что устранен запрет на управление имуществом доверителя.

В контексте взаимодействия с доверителем B.В. Раудин отметил необходимость запретить адвокатам обещать давать доверителю гарантии и важность получения письменного разрешения доверителя разглашать сведения. Также он указал, что появилась обязанность адвоката отвечать на требование доверителя сообщать ему информацию.

В сфере денежных взаимоотношений с доверителем он указал, что разрешено получение аванса, но по-прежнему запрещена передача имущества. Также он подчеркнул, что в предыдущей редакции Кодекса профессиональной этики адвоката содержался запрет на переуступку адвокатом требования к доверителю.

Следующим докладчиком стала М.В. Глухова, адвокат Московской областной коллегии адвокатов, кандидат экономических наук - она выступила с докладом на тему «Особенности работы адвоката в рамках оказания юридической помощи отдельным категориям населения». Основное внимание она сосредоточила на особенностях оказания адвокатами помощи в такой важной сфере, как помощь детяминвалидам, и отметила, что нужно расширить перечень прав, на которые может рассчитывать ребенок-инвалид. Среди прочих проблем, возникающих в связи с оказанием адвокатом соответствующей помощи, М.В. Глухова отметила коллизию взаимоотношений адвокатских палат, если адвокат хочет оказать бесплатную юридическую помощь детям из другого субъекта России.

Далее выступил В.Н. Ивакин, доцент кафедры адвокатуры и нотариата Университета имени О. Е. Кутафина (МГЮА), кандидат юридических наук, доцент, с докладом на тему «Формирование адвокатуры в Западной Европе». Его доклад представлял собой историкоправовое исследование истории адвокатуры в Европе на примере возникновения, становления и развития адвокатуры во Франции. Он отметил, что отправной точкой его интереса к истории адвокатуры стало то, что заявленный им в диссертации на соискание ученой степени кандидата юридических наук тезис о том, что представитель не является помощником правосудия, вызвал критику со стороны многих теоретиков.

В.Н. Ивакин подчеркнул, что оседлость парижского парламента, установившаяся в 1302 г., привела к тому, что практиковавшие при нем адвокаты по примеру Древнего Рима создали сословие (ordo), назвав его так в противовес цехам. Адвокатура во Франции не создавалась королем, а возникла сама. Клятва вести только правые дела была предусмотрена по подобию римской клятвы; впервые требовалась в п. 1 ордонанса 1272 г. Впоследствии текст присяги был расширен.

Также В.Н. Ивакин указан на встречающееся смешение понятий ««гонорар успеха» и «pactum quota litis» - последнее является запретом на получение части присужденного имущества; он подчеркнул, что в некоторых странах Европы (Германия, Голландия) нашли выход в введении бонусной системы.

B XIV веке появилось 2-е условие - внесение в список. Далее был введен экзамен, но предусматривалась возможность замены его сбором сведений, а образование проверялось наличием диплома лиценциата прав; специального квалификационного экзамена не было. Формально требование обязательного наличия диплома отсутствовало, но судя по спискам, все адвокаты имели такие дипломы.

Далее В.Н. Ивакин привел исторические примеры имевших важное историческое значение услуг, оказанных юристами королям Франции (в борьбе против политических притязаний римского папства и в обоснование «салического закона», предусматривающего переход права на престол только по мужской линии).

Следующим докладчиком стал С.Ю. Макаров, доцент кафедры адвокатуры и нотариата Университета имени О. Е. Кутафина (МГЮА), кандидат юридических наук, адвокат. Он выступил с докладом «Взаимодействие адвокатуры и магистратуры (государственной службы) как исторический принцип европейской адвокатуры, и восприятие его в России». Основываясь на обозначении Е.В. Васьковским отсутствия связи адвокатуры с магистратурой в качестве одного из принципов дореволюционной присяжной адвокатуры, он отметил, что этот принцип явно был воспринят из адвокатуры австро-германского типа - в противовес адвокатуре англо-французского типа. Далее С.Ю. Макаров подчеркнул, что и в Древнем Риме, и во Франции Средних веков и Нового времени - то есть в тех странах, где в разные эпохи сложилась адвокатура в ее классическом понимании - адвокатура существовала в тесном взаимодействии с магистратурой, которое проявлялось в том, что адвокаты пригла- 
шались для замещения судейских должностей, а также для занятия высоких государственных должностей. В отношении Древнего Рима он привел цитаты из писем известного римского адвоката, политика и литератора рубежа I и II веков от Р.Х. Плиния Младшего по рассматриваемой теме, а также отметил, что все комиссии по подготовке кодификации римского права и законодательства при императоре Юстиниане в значительной степени состояли из адвокатов. В отношении Франции С.Ю. Макаров упомянул, что адвокаты часто приглашались для занятия высших государственных должностей - канцлера и хранителя печати.

В отношении же дореволюционной России докладчик отметил, что вплоть до февраля 1917 года приглашение адвокатов для замещения судейских должностей, а тем более для занятия высоких государственных должностей (министров) было невозможно из-за опасения оппозиционности присяжной адвокатуры, вплоть до ее революционности - в свете воспоминаний о революционности французских адвокатов, некоторые из которых приняли активное участие в событиях Великой Французской революции XVIII века. Приведя известную цитату из беседы императора Николая I с князем Голицыным, С.Ю. Макаров отметил, что из трех упомянутых государем императором в обоснование неприятия создания профессиональной адвокатуры революционеров адвокатом был только один (Робеспьер) - однако широко распространенное мнение об устройстве революции адвокатами долго влияло на отношение к этому вопросу правителей России. И кроме того, несомненная оппозиционность и даже некоторая революционность российской присяжной адвокатуры также крайне отрицательно влияла на саму возможность положительного взаимодействия адвокатуры и магистратуры, то есть государства, что, разумеется, имело отрицательные последствия и для адвокатуры, и для государства.

Далее выступил О.В. Поспелов, доцент кафедры адвокатуры и нотариата Университета имени О. Е. Кутафина (МГЮА), кандидат юридических наук, адвокат, с докладом по теме «Российский и зарубежный опыт профессионального усовершенствования адвокатов». Он обратил внимание участников круглого стола на принципиальный отказ советов присяжных поверенных на протяжении всей истории их существования от самой идеи обязательного повышения квалификации присяжных поверенных, поскольку рассматривая жалобы на членов сословия, советы сформулировали презумпцию профессионализма присяжного поверенного, обязанного самостоятельно изучать законодательство по каждому принятому им делу.
Обязанность повышать квалификацию была введена советской властью в 1939 году в отношении советских адвокатов и с тех пор воспроизводится в последующем законодательстве об адвокатуре вплоть до Федерального закона об адвокатской деятельности 2002 года. Устоявшийся в отечественном законодательстве термин «повышение квалификации адвоката» усредняет подход ко всем адвокатам, не учитывает в полной мере их профессиональную индивидуальность и реальные потребности. Переход к системе «профессионального усовершенствования адвоката» позволил бы выстраивать каждому адвокату свою программу существования в профессии (возможно, по согласованию с коллегами из адвокатского образования), шлифуя навыки адвокатской деятельности в рамках избранной специализации. Подобный переход можно было бы осуществить при заимствовании положительного опыта зарубежных адвокатских ассоциаций, которые широко используют электронные возможности накопления и распространения профессиональной информации, интересующей адвокатов.

Следующими выступили Е.А. Белоотченко и М.Е. Егорова, являющиеся соискателями кафедры адвокатуры и нотариата Университета имени О. Е. Кутафина (МГЮА) и помощниками нотариуса, с докладом на тему «Новое в законодательстве о нотариате. Сравнительный анализ предыдущих и действующих Основ законодательства Российской Федерации о нотариате». Они прокомментировали изменения, внесенные в Основы законодательства Российской Федерации о нотариате. Также они отметили важность государственной поддержки нотариата и возможность аренды без конкурса помещений, находящихся в государственной собственности. Кроме того, они прокомментировали такие нововведения, как механизм внесения сведений о залоге движимого имущества на основании заявлений в письменной или электронной форме, введение реестров наследственных дел в электронной форме, равнозначность документа на бумажном носителе и электронного документа.

Далее они отметили необходимость внесения следующих изменений: 1) реформа организационно-правовых форм нотариальной деятельности путем окончательного упразднения госконтор; 2) необходимость соблюдения правил профессиональной этики; 3) необходимость придания нотариальному акту доказательственной силы; 4) необходимость придания нотариальному акту исполнительной силы; 5) необходимость закрепления обязательности повышать квалификацию.

Далее с докладом на тему «Презумпция невиновности как гарантия независимости 
адвоката в уголовном процессе» выступил Г.И. Сибирцев, преподаватель, аспирант кафедры организации судебной власти и правоохранительной деятельности Воронежского государственного университета. Он отметил важность двух факторов: независимости как отсутствия постороннего влияния на адвоката и самостоятельности как возможности выступать от своего имени и нести ответственность. Закончил свое выступление Г.И. Сибирцев цитатой М.С. Строговича о том, что разными могут быть результаты судопроизводства, но одно неизменно - защитник не должен отождествляться с обвиняемым.

После этого Д.В. Шарапова, аспирант кафедры уголовно-процессуального права Университета имени О.Е. Кутафина (МГЮА), выступила с докладом на тему «К вопросу о статусе помощника и стажера адвоката». Давая обзорную характеристику статуса стажера и помощника адвоката, она отметила, что в большинстве случаев стажеры и помощники фактически получают только навыки юридического письма, в то время как необходимо предоставление им реальной возможности выступать в судах.

Также она высветила проблему обязанности стажеров и помощников адвоката хранить адвокатскую тайну при отсутствии в уголовно- процессуальном законе запрета допрашивать их и запрета проводить у них обыски.

Затем И.И. Донцова, аспирант кафедры адвокатуры и нотариата Университета имени О.Е. Кутафина (МГЮА), выступила с докладом на тему «Порядок образования, структура и функции Федеральной палаты адвокатов Российской Федерации». В нем она отметила значение Федеральной палаты адвокатов России для юристов и для всего общества в связи с тем, что она возглавляет и объединяет адвокатскую корпорацию.

В завершение работы секции выступил Е.В. Орешин, аспирант кафедры адвокатуры и нотариата Университета имени О. Е. Кутафина (МГЮА), с докладом на тему «Теории принятия поручений на ведение дела адвокатами», в котором охарактеризовал две существующие теории - теорию закономерности и теорию избирательности - и сравнил их по важнейшим критериям.

Работа секции адвокатуры и нотариата прошла весьма успешно, поскольку доклады, с которыми выступали участники ее работы, благодаря своей многогранности позволили высветить и обсудить весьма разнообразные проблемы современного состояния адвокатуры и нотариата России, а в результате этого наметить пути преодоления этих проблем.

Материал поступил в редакцию 27 апреля 2014 г. 